\title{
Advertorial|KIT DIAGNOSTIK DIFTERI BERBASIS HIBRIDISASI DNA
}

\author{
Billgerd Tjengal, ${ }^{1}$ Almira Alifia, ${ }^{2}$ Novia Syari Intan ${ }^{2}$ \\ ${ }^{1}$ Sains dan Teknologi Farmasi, Sekolah Farmasi, Institut Teknologi Bandung, \\ Bandung \\ ${ }^{2}$ Mikrobiologi, Sekolah Ilmu dan Teknologi Hayati, Institut Teknologi Bandung, \\ Bandung \\ Coresponding author's email : bilgerd.tjengal@gmail.com
}

\begin{abstract}
ABSTRAK
Pendahuluan: Difteri merupakan penyakit infeksi saluran pernapasan atas yang disebabkan oleh bakteri Corynebacterium diphtheria. Kemunculan kembali wabah difteri menyebabkan kematian dalam jumlah banyak dan dalam kurun waktu cepat. Hal ini diakibatkan karena tidak adanya metode diagnosis difteri yang cepat dan tepat. Metode diagnosis umum yang saat ini dilakukan adalah kultivasi bakteri dan metode ini membutuhkan waktu yang cukup lama, yaitu 3 hingga 5 hari, dengan kondisi pasien yang mungkin sudah sangat parah ketika hasil diagnosis tersebut dapat dirilis. Oleh karena itu, dibutuhkan metode diagnosis difteri yang sensitif, mudah dan cepat sehingga pasien yang diduga terjangkit dapat ditangani dengan lebih cepat.

Metode: Advertorial ini ditulis berdasarkan metode penelusuran pustaka.

Hasil: Kit diagnostik difteri dirancang berdasarkan metode hibridisasi DNA menggunakan metode DNA microarray. Pada pelat microarray terdapat probe berupa fragmen DNA untai tunggal yang merupakan komplemen dari daerah unik berupa gen pengkode protein toksin difteri. Sampel uji diperoleh dari preparasi sampel apusan tenggorokan pasien kemudian dilabeli dengan penanda fluoresensi dan diteteskan ke pelat. Dengan demikian, jika terdapat DNA difteri di dalam sampel maka akan terjadi hibridisasi antara DNA difteri dengan probe. Terjadinya hibridisasi akan ditandai dengan fluoresensi yang merupakan indikator pasien terjangkit difteri atau tidak. Pengaplikasian kit diagnostik ini dapat mempersingkat proses diagnosis $C$. diphtheria menjadi kurang dari 24 jam.

Kesimpulan: Kit Diagnostik Difteri berbasis hibridisasi DNA dapat dibuat dan diterapkan.
\end{abstract}

Kata kunci: Difteri, DNA microarray, hibridisasi DNA, kit diagnostik

\section{ABSTRACT}

Introduction: Diphtheria is an upper respiratory tract infection caused by Corynebacterium diphtheria bacterium. The recent diphtheria outbreak caused a large number of deaths in rapid period. This is due to the absence of a fast and precise method of diphtheria diagnosis. Current diagnosis practices are done by cultivating bacteria which takes a relatively long time, which is 3 to 5 days, while the patients may already develop severe infection by the time the results are accessible. Therefore, a sensitive, easy and fast diphtheria diagnostic method is needed so that patients suspected of being infected can be treated quicker.

Methods: This advertorial is written based on literature study method.

Result: The diphtheria diagnostic kit was designed based on the DNA hybridization method by using DNA microarray. There are probes on the microarray plate in the form of a single stranded DNA fragment that is complement to the unique area of gene that encodes diphtheria toxin. The test sample was obtained from the preparation of the patient's throat smear and labeled with a fluorescence marker before dropped onto the plate. Thus, if there is diphtheria DNA in the patient's sample, hybridization will occur between diphtheria DNA and the complementary DNA probe. The occurrence of hybridization will be characterized by fluorescence as an indicator of whether patients have diphtheria or not. The application of this diagnostic kit can shorten the diagnosis of $C$. diphtheria to less than 24 hours Conclusion: Diphtheria diagnostic kit based on DNA hybridization can be made and applied

Keywords: lung cancer, chemopreventive, soursop, nanoparticles, aerosol 


\section{PENDAHULUAN}

Difteri merupakan penyakit infeksi saluran pernapasan atas akut yang disebabkan infeksi Corynebacterium diphtheriae. Selain menginfeksi faring, tonsil, dan hidung; bakteri ini mampu menghasilkan toksin yang secara sistemik dapat menyebabkan banyak komplikasi penyakit, bahkan kematian. Difteri menjadi masalah kesehatan yang dipandang serius di Indonesia karena meskipun telah dilakukan pencegahan dengan vaksinasi massal tahun 1998, jumlah kasusnya terus berfluktuasi, terutama sejak tahun 2002. Terakhir, pada tahun 2017 kembali terjadi outbreak difteri di Indonesia dengan dilaporkannya paling tidak 596 kasus dan 30 kematian akibat difteri (Harapan, et al, 2018). Berdasarkan data yang dikumpulkan oleh $\mathrm{WHO}$ (World Health Organization) tiap tahunnya, fluktuasi kasus difteri di Indonesia yang dilaporkan juga terjadi, dan terjadi lonjakan besar jumlah kasus difteri pada tahun 2003, 2012, dan 2017.

Tabel 1.1 Data kasus difteri di Indonesia 1999-

\begin{tabular}{|c|c|c|c|}
\hline \multicolumn{1}{|c|}{$2018(\mathrm{WHO}, 2018)$} \\
\hline Tahun & $\begin{array}{c}\text { Jumlah } \\
\text { Kasus } \\
\text { Tercatat }\end{array}$ & Tahun & $\begin{array}{c}\text { Jumlah } \\
\text { Kasus } \\
\text { Tercatat }\end{array}$ \\
\hline 1999 & 114 & 2009 & 189 \\
\hline 2000 & 23 & 2010 & 432 \\
\hline 2001 & 34 & 2011 & 806 \\
\hline 2002 & 51 & 2012 & 1192 \\
\hline 2003 & 402 & 2013 & 775 \\
\hline 2004 & 197 & 2014 & 430 \\
\hline 2005 & 499 & 2015 & $\begin{array}{c}\text { (tak } \\
\text { tercatat) }\end{array}$ \\
\hline 2006 & 432 & 2016 & 342 \\
\hline 2007 & 183 & 2017 & 954 \\
\hline 2008 & 219 & 2018 & 1026 \\
\hline
\end{tabular}

Selain upaya preventif, tindakan kuratif juga perlu dipersiapkan demi menyelamatkan penderita dari dampak infeksi yang lebih lanjut. Perlu dilakukan diagnosis yang akurat untuk membedakan pasien difteri dengan pasien lainnya. Saat ini, metode diagnosis difteri didasarkan pada gejala umum seperti adanya keluhan sakit tenggorokan dan demam serta pada akhirnya terbentuk lapisan pseudomembran putih keabuan di area faring. Untuk memastikannya, dilakukan uji keberadaan C. diphtheriae pada pasien melalui serangkaian tahap di laboratorium yang salah satunya melibatkan tahap kultivasi (Mustafa, et al, 2016). Akan tetapi, metode kultur tersebut memerlukan waktu yang cukup lama, sementara pasien harus segera diobati karena pembentukan pseudomembran tersebut dengan cepat mengganggu proses pernapasan pasien. Selain itu, dikhawatirkan pula toksin C.diphtheriae menyebar secara sistemik dan menyebabkan kerusakan lebih lanjut (Hadfield, et al,2000). Oleh karena itu, diperlukan sebuah metode diagnosis difteri yang lebih mudah dan cepat agar pasien dapat segera mendapat pengobatan yang tepat sasaran.

Dalam karya tulis ini diusulkan rancangan kit diagnosis difteri yang berbasis hibridisasi DNA. Kit ini berprinsip mendeteksi keberadaan C. diphtheriae pada sampel melalui hibridisasi sekuens DNA khas yang dimiliki C. diphtheriae, dengan probe DNA komplemennya. Metode ini dapat pula digunakan untuk membedakan penyakit difteri dengan penyakit pernapasan lain yang memiliki gejala serupa karena dilengkapi probe DNA untuk mengenali keberadaan patogen lain. Proses pengujian sampel dari awal preparasi hingga diperoleh kesimpulan hanya memakan waktu kurang dari 24 jam. Pengenalan yang spesifik juga diharapkan mampu mendeteksi 
keberadaan C. diphtheriae pada jumlah rendah, sebelum terbentuk pseudomembran pada faring. Dengan begitu diharapkan pasien difteri bisa mendapat pertolongan yang lebih cepat dan secara luas dapat membantu ketanggapan pemerintah dalam mengatasi kasus outbreak.

Tujuan dari artikel ini adalah untuk membuat rancangan kit kit diagnostik difteri berbasis hibridisasi DNA yang mudah dan cepat. Manfaatnya adalah dengan Adanya kit ini dapat membantu diagnosis penyakit difteri pada pasien sehingga penanganan yang cepat dan tepat sasaran dapat dilakukan. Dengan begitu, diharapkan semakin banyak pasien yang dapat diselamatkan.

\section{PEMBAHASAN}

\subsection{Difteri}

Difteri adalah penyakit infeksi yang disebabkan oleh bakteri Corynebacterium diphtheriae. Gejala dari penyakit ini utamanya disebabkan oleh toksin yang dihasilkan dari bakteri tersebut. Toksin difteri mampu menginduksi koagulum yang terdiri dari fibrin, leukosit, dan sel-sel epitel saluran pernapasan yang mati. Koagulum tersebut membentuk pseudomembran berwarna putih keabuan yang menyumbat saluran pernapasan sehingga menyebabkan sesak napas pada pasien. Hal tersebut menjadi penyebab utama kematian penderita difteri. Selain itu, toksin yang menyebar secara sistemik juga dapat menyebabkan kerusakan organ dalam dan mengakibatkan komplikasi seperti myocarditis, penyakit ginjal, dan saraf (Mustafa, et al, 2016).

\subsection{Corynebacterium diphtheriae}

C. diphtheriae merupakan bakteri Gram positif berbentuk basil dan bersifat aerob. Bakteri ini umumnya hanya mengakibatkan infeksi pada saluran pernapasan atas (upper respiratory tract). Selain itu, C. diphtheriae juga terkadang dapat mengakibatkan infeksi pada lambung, paru-paru, membran kulit dan organ lainnya (Wilson dan Menson, 2018) (Hadfield, et al., 2000). Terdapat empat subspesies (biotype) difteri, yaitu: C. d. mitis, C. d. intermedius, C. d. gravis, and C. d. belfanti. Keempat subspesies ini dapat dibedakan dengan beberapa cara seperti ukuran koloni pada media padat, karakteristik pertumbuhan di media cair dan kemampuan memfermentasi pati dan keparahan penyakit yang dihasilkan (Coyle, 1993).

\subsection{Epidemiologi Difteri}

Di dunia, difteri merupakan salah satu penyebab kematian anak-anak sebelum adanya vaksin. Di Amerika Serikat, pada tahun 1900 Difteri merupakan satu dari sepuluh penyakit dengan angka kematian tertinggi. Saat ini, kasus difteri telah berkurang secara signifikan setelah adanya vaksin difteri sejak tahun 1923. Walau demikian, kasus difteri tetap terjadi hingga saat ini dengan perkiraan sebanyak 5000 kasus per tahun. (WHO, 2017). Di Indonesia sendiri, outbreak difteri baru-baru ini terjadi pada tahun 2017. Hingga akhir November 2017 ada 95 kabupaten dan kota dari 20 provinsi yang melaporkan kasus difteri. Secara keseluruhan terdapat 596 kasus dan 30 diantaranya meninggal dunia. (Harapan, et al, 2018). Pada daerah endemis difteri, sekitar 5\% diantara penduduk sehat kemungkinan terjangkit difteri (Barroso, et al, 2017).

\subsection{Gejala dan Patogenesis}

Difteri menimbulkan gejala dan tanda berupa demam yang tidak begitu tinggi yaitu sekitar $38^{\circ} \mathrm{C}$, munculnya pseudomembran di tenggorokan yang berwarna putih keabu-abuan 
yang mudah berdarah jika dilepaskan, timbul rasa sakit ketika menelan, kadang-kadang disertai pembesaran kelenjar getah bening leher dan pembengkakan jaringan lunak leher yang disebut bullneck.

Difteri dapat ditularkan melalui kontak dengan materi infektif dari penderita (contohnya cairan dari saluran pernapasan / luka difteri) secara langsung atau melalui udara (Barroso, et al, 2017). C. diphtheriae melokalisasi saluran pernapasan atas, melukai lapisan mukosa, serta memperbanyak diri pada permukaannya sehingga memicu terbentuknya pseudomembran. Pseudomembran dapat menghalangi jalur masuknya udara pada pasien dan pada akhirnya menyebabkan sianosis dan asfiksia. C.diphtheriae juga memproduksi toksin yang dapat masuk ke sistem peredaran darah. Toksin ini dapat mengganggu proses sintesis protein pada sel penderita dengan cara menginaktivasi elongation factor 2 (EF-2) dan dapat menyebabkan kematian sel (Collier, 1967). Toksin difteri tidak menyerang organ spesifik, namun seringkali ditemukan menyerang otot jantung dan syaraf (Hadfield, et al, 2000).

\subsection{Genom Difteri dan Gen tox}

C. diphtheriae NCTC13129 memiliki ukuran genom sebesar 2.488.635 pasang basa dengan GC content sebesar 53,48 \% dan coding density sebesar 87,9\%. Gen pengkode toksin difteri adalah gen khas difteri toksigenik yang mengkodekan produksi racun tox, terletak di dalam kromosom C. diphtheriae dan memiliki panjang gen sebesar 1.680 pasang basa (Cerdeno-Tarraga, 2003). Gen tersebut hanya dimiliki oleh C. diphtheriae yang terinfeksi corynebacteriophages, Beberapa strain yang sangat toksik memiliki dua atau tiga gen tox terinsersi pada kromosomnya. Ekspresi gen tox dipicu oleh konsentrasi besi yang rendah (Hadfield, et al, 2000).

\subsection{Metode Diagnosis yang Telah Ada}

Diagnosis difteri umumnya dilakukan setelah timbul gejala berupa demam, rasa sakit pada tenggorokan, serta yang paling khas adalah adanya pseudomembran berwarna keabuan pada daerah faring. Untuk analisis lebih lanjut, dilakukan pengambilan sampel apusan tenggorokan pasien dengan memastikan bagian di bawah membran juga terambil. Sampel tersebut kemudian dianalisis untuk mengetahui keberadaan C. diphtheriae melalui metode kultivasi dengan medium selektif yaitu blood agar atau medium yang mengandung tellurite. Tellurite mampu menghambat pertumbuhan mikroflora normal pada medium, sementara C. diphtheriae mampu mereduksi garam tellurite dan tumbuh membentuk koloni berwarna kehitaman. Meski dapat digunakan, uji tersebut memiliki kekurangan yakni C. diphtheriae yang tidak mudah diidentifikasi pada blood agar membuat hasil uji sulit disimpulkan. Selain itu, apabila jumlah bakteri target pada spesimen terlalu sedikit, dikhawatirkan bakteri tersebut tidak dapat tumbuh pada media dikarenakan kalah bersaing dengan mikroba lain. Untuk menyimpulkan hasil uji menggunakan tahap kultivasi juga memerlukan waktu berhari-hari tergantung kecepatan pertumbuhan mikroba target (Efstratiou, et al, 2000).

Uji lain adalah dengan pengamatan spesimen secara langsung di bawah mikroskop, namun hal ini tidak direkomendasikan karena beresiko tinggi terjadi false-negative maupun false-positive. Uji biokimia juga dapat dilakukan karena C. diphtheriae memiliki karakteristik biokimia tertentu. Meskipun cukup spesifik, uji ini juga memerlukan waktu yang cukup lama dan 
harus dilakukan sejumlah uji untuk mendapat hasil yang akurat.

Terdapat pula uji berdasarkan toksigenisitas, yaitu Elek immunoprecipitation test yang berprinsip mendeteksi toksin difteri dengan antitoksin. Bentuk lain dari uji yang didasarkan pada keberadaan toksin adalah uji enzyme immunoassay (EIA), yaitu dengan mengenali fragmen $A$ pada molekul toksin difteri menggunakan antitoksin poliklonal yang akan dideteksi oleh antitoksin monoklonal terlabel alkalin fosfatase. Namun, kelemahan dari metode ini yaitu kadar toksin difteri pada tubuh pasien harus mencapai level tertentu agar dapat dianalisis dengan metode ini, sehingga tidak dapat digunakan pada pasien yang baru saja terinfeksi.

Terakhir, metode diagnosis difteri yang lainnya adalah dengan pendekatan molekuler dengan reaksi PCR (Polymerase Chain Reaction) yaitu amplifikasi gen pengkode toksin difteri dengan primer yang didesain khusus. Uji tersebut dinilai efektif karena cepat dan spesifik, meskipun masih kerap terdapat hasil false negative jika menggunakan sampel langsung dari pasien (Efstratiou, et al 2000).

\subsection{Metode Hibridisasi DNA}

Hibridisasi DNA merupakan metode yang umum digunakan dalam berbagai analisis molekuler dalam berbagai kasus contohnya analisis taksonomi, epidemiological screening, serta patologi forensik. Metode ini berprinsip pada hibridisasi yang akan terjadi pada kondisi tertentu antara untai tunggal fragmen DNA target dengan probe DNA yang saling berkomplemen. Hibridisasi dapat terjadi akibat dua peristiwa yaitu interaksi koloidal dan interaksi pasangan basa. Interaksi koloidal mampu memicu untai DNA untuk saling mendekat terlepas dari kecocokan urutan/sekuens-nya. Setelah itu, pada jarak untai DNA tunggal yang berdekatan, akan terjadi interaksi yang memicu untai DNA "mencari" komplemennya untuk melengkapi proses hibridisasi. Proses hibridisasi dipahami sebagai reaksi yang sangat dipengaruhi oleh kondisi lingkungannya sehingga diperlukan pemahaman mengenai hal tersebut. (Schmitt, et al,2013).

Hibridisasi diharapkan terjadi antara probe DNA dengan sampel. Desain probe DNA juga harus diperhatikan untuk meningkatkan spesifisitas dan mencapai efisiensi yang tinggi. Probe DNA dapat berupa probe gen yang terdiri atas sekitar 500 pasang basa yang secara spesifik menarget sekuens tertentu. Selain itu probe DNA juga dapat berupa oligonukleotida yang relatif pendek.

Menurut Walker dan Rapley (2008), ada beberapa syarat probe oligonukleotida DNA yang baik antara lain:

- Panjang probe harus berada di rentang 18 hingga 50 basa. Probe yang terlalu panjang akan membuat perolehan sintesis probe kecil dan waktu hibridisasi menjadi lebih lama. Probe yang terlalu pendek akan memiliki spesifisitas yang lebih rendah;

- Komposisi GEC (GC Content) sekitar 40$60 \%$;

- Tidak terdapat daerah komplemen internal dalam probe, sebab dapat terbentuk struktur mirip jepit rambut (hairpin) yang dapat mengakibatkan hibridisasi dengan sampel tidak dapat terjadi;

- Sebaiknya tidak memiliki basa tunggal yang lebih dari empat kali berturut-turut dalam satu susunan.

Probe yang dirancang untuk melakukan hibridisasi dapat ditempelkan pada membran, pendukung solid, maupun cair. Fasa-fasa tersebut berpengaruh pada kinetik hibridisasi yang akan terjadi (Narayanan, 1992). 
Metode hibridisasi DNA kini umum digunakan sebagai metode diagnosis penyakit tertentu, dengan prinsip dasar mendeteksi keberadaan patogen penyebab penyakit tersebut yang ditandai dengan keberadaan sekuens gen khas yang dimiliki pada materi genetiknya. Oleh karena itu, pada metode hibridisasi DNA, setiap probe dirancang khusus untuk berkomplemen dengan sekuens target yang ingin dideteksi (Marti, et al., 2007).

Selain itu, dibutuhkan pula label deteksi, yang akan menunjukkan sinyal tertentu ketika hibridisasi terjadi, supaya dapat diamati jika sekuens target yang dicari memang ada di dalam sampel dan berhibridisasi dengan probe yang sesuai (Marras, 2006). Terdapat beragam jenis probe, umumnya menggunakan prinsip deteksi fluoresensi, yaitu akan teramati pendaran jika terjadi hibridisasi (Jukoswiak, 2011).

\subsection{Penjelasan Umum Kit}

Kit diagnostik difteri yang dirancang merupakan kit untuk mendeteksi keberadaan C. diphtheriae pada sampel pasien. Kit ini berbasis pada hibridisasi DNA yang akan terjadi pada probe DNA yang menarget sekuens DNA pengkode toksin difteri milik C. diphtheriae.

Selain secara spesifik mendeteksi keberadaan C. diphtheriae, kit ini juga dapat dilengkapi dengan probe DNA untuk deteksi patogen lain yang menyebabkan berbagai penyakit pernapasan mirip seperti difteri. Diharapkan, pasien dapat mendapatkan penanganan yang tepat untuk penyakitnya, terutama dalam bahasan ini, untuk penyakit difteri.

\subsection{Prinsip Deteksi}

DNA genom yang diperoleh kemudian akan direstriksi. Restriksi dilakukan dengan satu jenis enzim yang akan memotong genom menjadi
Kit ini menggunakan metode hibridisasi solid, yaitu probe DNA akan diimobilisasi pada permukaan material plastik, sementara sampel yang telah diberikan perlakuan akan diteteskan diatasnya. Probe tersebut adalah oligonukleotida yang berkomplemen dengan sebagian daerah gen pengkode toksin pada C. diphtheriae (gen tox), sepanjang $\leq 50 \mathrm{bp}$, yang paling conserved. Hal ini dilakukan berdasarkan pada literatur yang membahas penggunaan gen tersebut sebagai target untuk deteksi C. diphtheriae karena bersifat spesifik (Efstratiou, et al, 2000).

Sementara itu, untuk deteksi patogen lainnya ditentukan masing-masing sekuens yang bersifat spesifik sebagai probe, dan mampu membedakan patogen tersebut dengan difteri (Efstratiou, et al, 2000). Contohnya adalah oligonukleotida dari daerah gen 16S rRNA untuk bakteri (Sedghian, Pourmand, 2008) atau sekuens pengkode antigen untuk virus (Wang, et al, 2006).

Sebelum diuji menggunakan kit, dilakukan preparasi sampel yaitu isolasi DNA dan restriksi DNA hasil isolasi. Isolasi dilakukan untuk memperoleh DNA pada sampel, memisahkannya dari debris sel dan pengotor lainnya seperti karbohidrat dan protein. Isolasi DNA dilakukan dengan prinsip pemecahan sel bakteri secara kimia dengan bantuan surfaktan, dilanjutkan dengan pengendapan protein dan pengotor menggunakan kombinasi potassium dodecyl sulfate dan SDS, dan perolehan DNA menggunakan pengendapan dengan isopropanol (Tan, Yiap, 2009). Proses ini dapat dilakukan dalam 40 menit dengan bantuan kit komersial dengan prinsip yang sama.

oligonukleotida yang lebih kecil dan fleksibel. Pada studi microarray, struktur sekunder dan panjang molekul asam nukleat mempengaruhi laju 
dan efisiensi hibridisasi probe dengan DNA target (Liu,et al,2007). Genom memiliki ukuran yang besar dan dikhawatirkan dapat membuat halangan sterik yang menyulitkan pergerakannya sehingga mengurangi kesempatan sekuens target menempel dengan probe. Pada metode analisis fragmen DNA, perlakuan dengan enzim restriksi umum dilakukan untuk menghasilkan fragmen yang cukup pendek agar diperoleh efisiensi yang relatif lebih tinggi (Liu, et al, 2007).

Setelah itu, sampel didenaturasi pada suhu $95^{\circ} \mathrm{C}$ menggunakan heating block selama tiga menit hingga seluruh DNA menjadi untai tunggal, kemudian diberikan penanda fluoresensi pada masing-masing untainya. Sampel tersebut lalu diteteskan pada pelat berisi probe DNA, kemudian diatur kondisinya agar terjadi penempelan antara DNA yang saling berkomplemen, terutama dengan probe. Hibridisasi ini terjadi dengan peluang acak dan hanya memanfaatkan interaksi antar basa nukleotida untuk menempel dengan pasangannya (Narayanan, 1992). Sebelum dilakukan pembacaan fluoresensi, dilakukan pembilasan (washing) untuk memisahkan fragmen DNA yang tidak berpasangan dengan probe DNA. Probe yang berhasil berpasangan dengan fragmen DNA akan memicu munculnya fluoresensi. Fluoresensi tersebut menjadi indikator keberadaan DNA target dan akan dikuantifikasi dengan fluorometer (Narayanan, 1992).

\subsection{Komponen dalam Kit}

Kit yang dirancang terdiri atas beberapa komponen, yaitu DNA microarray slide, perangkat preparasi sampel, dan larutan-larutan pascahibridisasi. Dalam proses manufaktur komponen utama kit yaitu DNA microarray slide, pertamatama sekuens oligonukleotida marka difteri yang diambil dari gen pengkode toksin tox yang akan digunakan sebagai probe ditentukan. Selanjutnya, ditentukan pula sekuens oligonukleotida probe yang ditargetkan berhibridisasi dengan gen khas pada sejumlah patogen penyebab gangguan pernapasan lainnya. Setelah seluruh sekuens oligonukleotida probe diperoleh, maka oligonukleotida dengan sekuens yang diinginkan akan disintesis, kemudian diimobilisasi pada slide kaca yang telah dilapisi dengan senyawa kelompok amilosilane, misalnya 3aminopropiltrimetoksilane.

Kaca yang telah diberi perlakuan dengan senyawa itu akan bermuatan positif, sehingga memungkinkan interaksi dengan gugus negatif fosfat pada DNA, yang menyebabkan DNA terikat pada probe dengan pola tertentu pada permukaan solid dari kaca khusus yang dapat memfasilitasi ikatan dengan materi genetik, sehingga terbentuk DNA microarray slide.
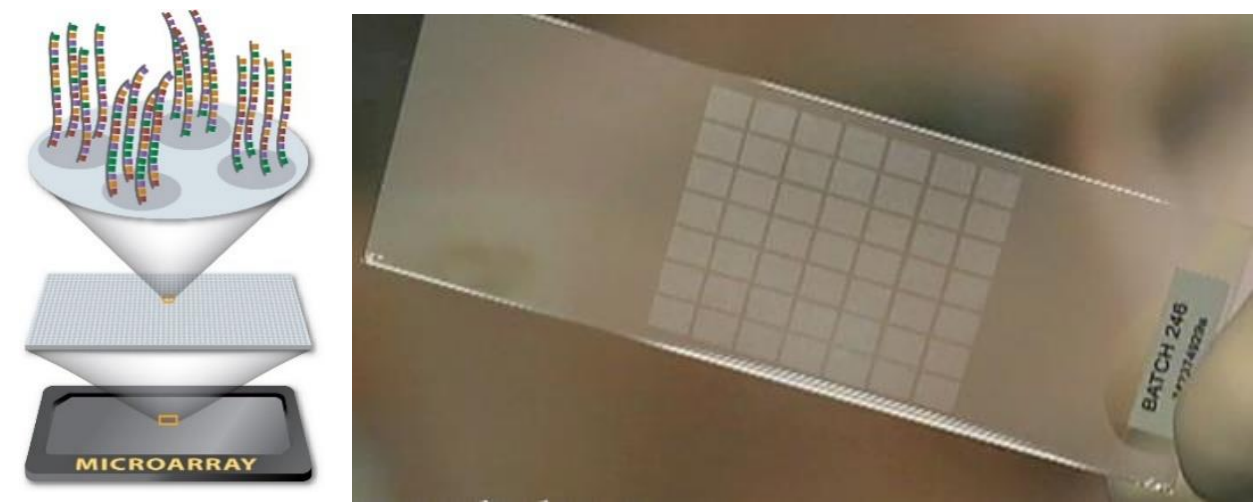

Gambar 3.1 Ilustrasi DNA microarray slide 
Preparasi sampel melingkupi proses ekstraksi DNA dan pre-hibridisasi. Dalam ekstraksi DNA, komponen-komponen yang dibutuhkan dan disediakan dalam kit adalah:

1. Lysis Buffer, mengandung surfaktan (deterjen) seperti Tween, Sebagai agen pendisrupsi membran sel, sehingga materi genetik yang terkandung dalam sampel dapat terekspos ke larutan.

2. Binding Buffer, mengandung chaotropic salt, sehingga memfasilitasi pelekatan DNA pada silica column untuk dapat diekstraksi.

3. Wash I Buffer, mengandung alkohol, sehingga melarutkan protein-protein yang menjadi pengotor dalam sampel.

4. Wash II Buffer, mengandung alkohol dengan kadar yang lebih kecil daripada Wash I Buffer, untuk memastikan seluruh elemen pengotor ikut terlarut.

5. Elution Buffer, memfasilitasi elusi DNA sehingga luruh dari silica column dan dapat diperoleh dalam bentuk larutan.

6. Silica Column, kolom dengan dasar berupa membran silika yang dapat berikatan dengan materi genetik, bertindak sebagai 'penyaring' DNA dari komponen non-materi genetik yang terdapat dalam sampel 7.Collection Tube, tub yang berfungsi mendukung terjadinya hibridisasi antara probe dengan DNA target.

Yang berikutnya, untuk proses pascahibridisasi, komponen-komponen yang dibutuhkan dan disediakan dalam kit adalah:

1. Hybridization Wash Buffer, berfungsi meluruhkan materi-materi genetik yang tidak terhibridisasi dengan probe pada DNA microarray slide.

2. Stripping Buffer, mengandung $\mathrm{NaOH}$ dan standard saline citrate, digunakan setelah proses pembacaan fluoresensi selesai dan diperoleh data menampung flow-through tahapan-tahapan ekstraksi DNA.

Sementara, dalam proses pre-hibridisasi, komponen-komponen yang dibutuhkan dan disediakan dalam kit adalah:

1. Restriction Enzyme, enzim restriksi universal yang berfungsi memotong-motong materi genetik dalam sampel, sehingga materi genetik berukuran lebih kecil dan mempermudah proses hibridisasi

2. Restriction Buffer, larutan penyangga yang menyediakan kondisi optimum enzim restriksi yang digunakan, sehingga proses restriksi dapat berjalan optimal.

3. Fluorophores, penanda fluoresens yang ditambahkan pada DNA sampel dengan interaksi yang dimediasi kompleks platina. Fluorophores akan berpendar menandai DNA yang berhibridisasi dengan probe.

4. Purification column, kolom untuk memurnikan DNA yang telah terlabeli dengan fluorophore.

5. Hybridization Buffer, mengandung standard saline citrate (SSC) sebagai penstabil pH serta sodium dodecyl sulphate (SDS) sebagai penurun tegangan permukaan, digunakan sebagai larutan penyangga materi genetik selama proses hibridisasi berlangsung yang yang diinginkan, berfungsi untuk membersihkan kembali probe dari DNA sampel yang telah berhibridisasi, sehingga DNA microarray slide dapat digunakan kembali sebanyak 5-6 kali.

\subsection{Kelebihan Kit Ini}

Kit diagnostik difteri yang diajukan dalam karya tulis ini memiliki sejumlah kelebihan seperti: - Preparasi sampel lebih mudah dibandingkan dengan metode immunoassay;

- Kit bisa dibawa kemanapun (portable), cepat, dan ergonomis; 
- $\quad$ Dapat membedakan difteri dengan penyakit pernapasan yang memiliki gejala serupa (multidiagnosis);

- Microarray plate bersama dengan probe bisa digunakan kembali (reusable);

- Dinilai lebih spesifik sebab menggunakan DNA;

- Tidak melibatkan tahap handling toksin sehingga relatif lebih aman;

- Kit mudah dioperasikan dan tidak banyak titik kritis saat pengerjaan;

- Hasil diagnosis dapat diperoleh dengan cepat, kurang dari 24 jam.

Sementara itu, kekurangan dari kit ini adalah biaya riset dan pengadaan kit terbilang mahal jika tidak diproduksi secara massal.

\subsection{Prospek Kit di Masa Mendatang}

Kit diagnostik difteri berdasarkan hibridisasi DNA ini masih membuka peluang untuk berbagai pembaharuan yang bermanfaat di kemudian hari. Untuk keperluan riset dan penggunaan obat-obatan yang lebih akurat, misalnya, dapat dirancang probe spesifik yang dapat membedakan antara strain difteri toksigenik dengan strain difteri NTTB (Non-toxigenic toxicbearing). Dapat dibedakan pula keempat biotype yang dimiliki oleh strain difteri toksigenik untuk keperluan riset lebih lanjut mengenai studi kasus difteri yang terjadi di berbagai penjuru dunia.

Dengan kit microarray ini pula, nantinya dapat dikembangkan kit multidiagnosis penyakit saluran pernapasan yang berpotensi pandemi, yaitu dengan penambahan jenis probe setiap ditemukannya penyakit pernapasan baru untuk mempercepat diagnosis yang berdampak pada waktu penanganan yang lebih singkat dan pemilihan metode penanganan yang lebih tepat, sehingga diharapkan kasus-kasus epidemi maupun pandemi akibat penyakit pernapasan dapat diminimalisasi.

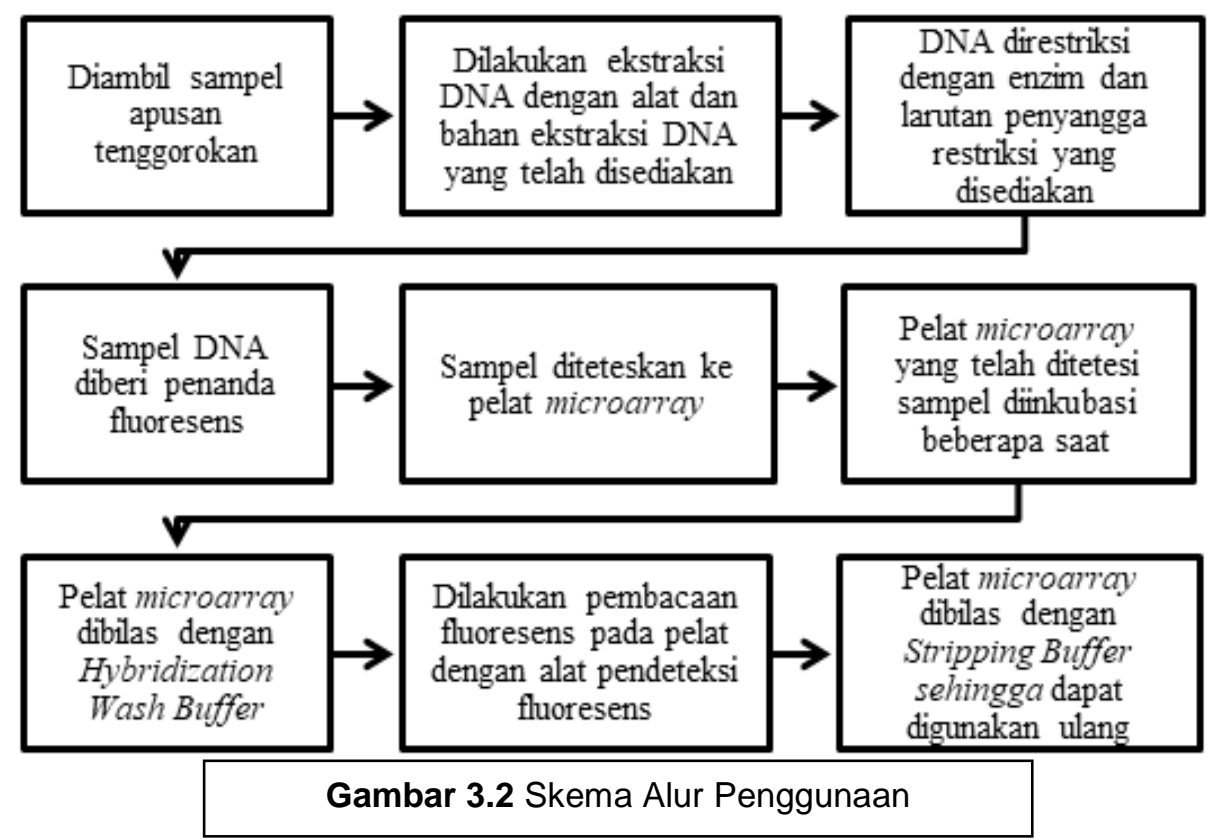




\section{KESIMPULAN}

Dari beragam tinjauan dan analisis data yang dilakukan, ditarik kesimpulan bahwa dapat dirancang sebuah metode alternatif diagnosis difteri yang cepat dan mudah berbasis hibridisasi DNA dalam bentuk kit DNA microarray.

\section{DAFTAR PUSTAKA}

[1] Barroso, L.F., Pegram, P.S., M.D., FACP. (2017). Epidemiology and Pathophysiology of Diphteria. [online]. https://www.uptodate.com/contents/epidemi ology-and-pathophysiology-of-diphtheria diakses pada 02 Oktober 2018

[2] Cerdeno-Tarraga, A. (2003). The complete genome sequence and analysis of Corynebacterium diphtheriae NCTC13129. Nucleic Acids Research, 31(22), pp.65166523.

[3] Efstratiou, A., Engler, K. H., Mazurova, I. K., Glushkevich, T., Vuopio-Varkila, J., \& Popovic, T. (2000). Current approaches to the laboratory diagnosis of diphtheria. Journal of Infectious Diseases, 181(Supplement_1), S138-S145.

[4] Guilfoile, P. (2009). Diphtheria. New York: Chelsea House.

[5] Hadfield, T., McEvoy, P., Polotsky, Y., Tzinserling, V. and Yakovlev, A. (2000). The Pathology of Diphtheria. The Journal of Infectious Diseases, 181(s1), pp.S116S120.

[6] Harapan, H., Anwar, S., Dimiati, H., Hayati, Z. and Mudatsir, M. (2018). Diphtheria outbreak in Indonesia, 2017: An outbreak of an ancient and vaccine-preventable disease in the third millennium. Clinical Epidemiology and Global Health.

[7] Juskowiak, B. (2011). Nucleic acid-based fluorescent probes and their analytical potential. Analytical and Bioanalytical Chemistry, 399(9), 3157-3176. http://doi.org/10.1007/s00216-010-4304-5

[8] Liu, W. T., Guo, H., \& Wu, J. H. (2007). Effects of target length on the hybridization efficiency and specificity of rRNA-based oligonucleotide microarrays. Applied and environmental microbiology, 73(1), 73-82.

[9] M.B.D. Coyle, J. Nowowiejski, J. Q. Russell, and N. B. Groman, "Laboratory Review of Reference Strains of Corynebacterium diphtheriae Indicates Mistyped Intermedius Strains," Journal of Clinical Microbiology 31, 11 (Nov. 1993): 3060-3062.

[10] Marras, S. A. (2006). Selection of fluorophore and quencher pairs for fluorescent nucleic acid hybridization probes. Methods. Mol. Biol., 335: 3-16.

[11] Marti, A. A., Jockusch, S., Stevens, N., Ju, J., Turro, N. J. (2007). Fluorescent Hybridization Probes for Sensitive and Selective DNA and RNA Detection. Acc. Chem. Res., 40: 402-409.

[12] Mustafa, M., Yusof, I., Jeffree, M., Illzam, E., Husain, S. and Sharifa, A. (2016). Diphtheria: Clinical Manifestations, Diagnosis, and Role of Immunization In Prevention. IOSR Journal of Dental and Medical Sciences, 15(08), pp.71-76.

[13] Narayanan, S. (1992). Overview of principles and current uses of DNA probes in clinical and laboratory medicine. Annals of Clinical \& Laboratory Science, 22(6), 353376.

[14] Nimse, S., Song, K., Sonawane, M., Sayyed, D. and Kim, T. (2014). Immobilization Techniques for Microarray: Challenges and Applications. Sensors, 14(12), pp.2220822229.

[15] R. Collier, "Effect of diphtheria toxin on protein synthesis: Inactivation of one of the transfer factors," Journal of Molecular Biology 25 (1967): 83-98.

[16] Schmitt, T. J., Rogers, J. B., \& Knotts IV, T. A. (2013). Exploring the mechanisms of DNA hybridization on a surface. The Journal of chemical physics, 138(3), 01B613.

[17] Sedghian H, Pourmand M. Molecular Detection of bacterial pathogens involved in urinary tract infection. Iran $\mathrm{J}$ Med Microbiol. 2008; 1 (4):41-45

[18] Tan, S. C., \& Yiap, B. C. (2009). DNA, RNA, and protein extraction: the past and the present. BioMed Research International, 2009:574398 
[19] Walker, J. and Rapley, R. (2008). Medical biomethods handbook. Totowa, N.J.: Humana Press, p.14.

[20] Wang, Z., Daum, L. T., Vora, G. J., Metzgar, D., Walter, E. A., Canas, L. C., ... \& Stenger, D. A. (2006). Identifying influenza viruses with resequencing microarrays. Emerging infectious diseases, 12(4), 638.

[21] Wilson, I. E., \& Menson, E. N. (2018). Cutaneous Diphtheria. New England Journal of Medicine, 378(13), e17.

[22] World Health Organization. (2017). Diphtheria. [online]. https://www.who.int/immunization/monitorin g_surveillance/burden/diphtheria/en diakses pada 03 Juni 2019.

[23] World Health Organization. (2018). Diphtheria. [online]. https://www.who.int/immunization/monitorin g 